\title{
Proses Pengambilan Keputusan Adopsi Inovasi Teknologi Budidaya Kedelai Jenuh Air (Kasus: Labuhan Ratu Enam, Lampung Timur)
}

D 0 I:10.18196/ agr.2230

\begin{abstract}
The expansion of crop land to suboptimal land (especially in the outside of Java Island) should be set up as source of agriculture crop production growth. Saturated-soil Cultivation (SSC) Technology is able to improve the productivity of soybean plants up to 4.0 tons/ha in the suboptimal land. This research is aims to examine the decision making process on innovation adoption of soybean Saturated-soil Cultivation (SSC) Technology, conducted in Labuan Ratu Enam Village, East Lampung Regency. Main approaches were used in this research is Rogers' theory of innovation diffusion. Decision process was divided into four main group of analysis: i) communication channel and general description of stages in the innovation decision, ii) influential variables of respondents' characteristics on the
\end{abstract}

knowledge stage using Kruskall-Wallis test, iii) influential variables of the innovation's attributes on the persuasion stage using Spearman Correlation test, and iv) correlation between the stages of innovation decision process using Spearman Correlation test and Mann-Whitney test. The results shows that i) interpersonal channel is chosen as the way to diffuse SSC innovation to 25 potential farmer adopters through discussion, direct practice, and guidance; ii) the influential variables of individuals' characteristics are leve of nonformal education and level of motivation, while level of formal education and farming experience is not significant difference in their knowledge level about SSC; iii) there is significant correlation between the level of respondents' persuasion and their perception on the innovation complexity and triability, but not compatability and observability; iv) each stage of SSC innovation-decision, one stage to another in sequence, has significant positive correlation.

Keywords: innovation adoption, saturated-soil cultivation, soybean

\section{INTISARI}

Perluasan areal panen ke lahan suboptimal (terutama di luar Pulau Jawa) dapat dijadikan sumber pertumbuhan pertanian yang produktif. Teknologi Budidaya Jenuh Air (BJA) mampu meningkatkan produktivitas tanaman kedelai hingga 4,0 ton/ha pada lahan suboptimal. Penelitian ini bertujuan untuk menggambarkanbagaimana proses pengambilan keputusan adopsi inovasi budidaya kedelai jenuh air berlangsung di Desa Labuhan Ratu Enam, Lampung Timur. Pendekatan yang digunakan dalam penelitian ini yaitu teori proses pengambilan keputusan inovasi (Rogers). Analisis tentang proses pengambilan keputusan dibagi ke dalam empat hal pokok: i) deskripsi jaringan komunikasi dan tahapan proses keputusan inovasi yang terbentuk, ii) variabel karakteristik responden yang berpengaruh pada tahap pengenalan, menggunakan uji KruskallWallis, iii) variabel karakteristik inovasi yang berpengaruh pada tahap persuasi, menggunakan uji Korelasi Spearman, dan iv) hubungan antar tahapan proses, menggunakan uji Korelasi Spearman dan Mann-Whitney. Hasil penelitian 
menunjukkan: i) saluran interpersonal adalah pendekatan yang dipilih untuk mengenalkan teknologi BJA kepada 25 petani adopter potensial melalui diskusi, praktik lapang, dan pendampingan; ii) variabel karakteristik petani yang berpengaruh adalah tingkat pendidikan nonformal dan motivasi, sedangkan berdasarkan tingkat pendidikan formal dan pengalaman usahatani, tingkat pengenalan petani terhadap BJA tidak berbeda nyata; iii) tingkat persuasi yang dirasakan oleh petani tentang BJA ternyata berhubungan secara signifikan dengan aspek kerumitan dan kemungkinan dicoba, namun tidak dengan kesesuaian dan kemungkinan diamati; iv) antartahapan dalam prosees keputusan inovasi BJA secara berurutan terbukti mempunyai hubungan positif yang signifikan.

Kata kunci: adopsi inovasi, jenuh air, kedelai

\section{PENDAHULUAN}

Kedelai merupakan komoditas multi purpose dan multi user dalam proses produksi, perdagangan, maupun pemanfaatannya sehingga kedelai menjadi salah satu komoditas pangan yang berperan penting dan memegang arti strategis di Indonesia (Supadi, 2009). Semakin meningkatnya jumlah penduduk dan meningkatnya kesadaran masyarakat akan kecukupan gizi, permintaan kedelai terus meningkat dari tahun ke tahun, dan berpotensi untuk terus meningkat di masa mendatang.

Areal panen kedelai terus mengalami penurunan disebabkan oleh areal panen yang terkonsentrasi di Pulau Jawa dan Bali, yaitu sebesar 71,8\%. Urutan selanjutnya adalah Sumatera (10,4\%), Nusa Tenggara (9,0\%), dan Sulawesi (7,0\%). Tingkat kebergantungan produksi pangan Indonesia yang sebagian besar (60\%) diproduksi di Pulau Jawa menjadi cukup riskan, kerana areal pertanian di Pulau Jawa semakin kompetitif dengan komoditas lain yang lebih menguntungkan (Ghulamahdi, 2009; Adisarwanto dan Wudianto, 2002), serta semakin tergerus seiring adanya konversi lahan.

Bagi negara berkembang, kemandirian pangan merupakan kunci utama untuk memperkokoh ketahanan pangan. Ketergantungan pada impor pangan dapat mengancam stabilitas sosial, ekonomi, dan politik (Rasahan, 1999 dan Baharsjah, 2004; dalam Supadi 2009). Oleh karena itu, perluasan areal panen kedelai hendaknya diperluas ke lahan suboptimal (Ghulamahdi, 2009; Sudana, 2005; Adisarwanto dan Wudianto, 2002). Lahan suboptimal antara lain lahan tidur, lahan kering, dan lahan rawa pasang surut.
Namun perluasan areal panen kedelai ke lahan rawa pasang surut bukan tanpa kendala. Lahan suboptimal (termasuk di dalamnya lahan rawa pasang surut) sering mengalami kekeringan, memiliki kandungan bahan organik rendah (kesuburan tanah yang rendah), termasuk kandungan unsur kimia tertentu yang menghambat pertumbuhan tanaman seperti $\mathrm{pH}$ yang rendah, kandungan $\mathrm{Al}, \mathrm{Mn}$, Fe yang bersifat racun bagi tanaman (Ghulamahdi, 2009; Makarim et. al., 2005). Namun di sisi lain, lahan rawa pasang surut (rawa yang genangannya dipengaruhi pasang surut air laut) memenuhi unsur-unsur iklim dominan yang mempengaruhi produksi kedelai, yaitu kecukupan ketersediaan air, radiasi/intensitas sinar matahari dan suhu yang tinggi (Irianto et. al., 2005; Ghulamahdi, 2009).

Salah satu teknologi budidaya yang dapat menjadi alternatif untuk peningkatan produktivitas di lahan suboptimal (lahan rawa pasang surut) adalah budidaya jenuh air (BJA). Teknologi BJA merupakan penanaman dengan memberikan irigasi terus menerus dan membuat tinggi muka air tetap tinggi, sehingga lapisan di bawah perakaran jenuh air (Hunter et. al., 1980). Pada beberapa penelitian skala demplot, potensi biologis kedelai BJA mencapai 4,0 ton/ha (Ghulamahdi, 2009). Dengan memperhitungkan risiko dan bias penerapan paket teknologi BJA, teknologi ini dapat meningkatkan produktivitas kedelai hingga 2,1 ton/ha-2,4 ton/ha.

Beragam inovasi pertanian yang didifusikan kepada petani tidak serta merta langsung diterima dan diterapkan oleh petani. Ditinjau sebagai proses komunikasi, difusi inovasi adalah proses membawa ideide baru dari pencipta atau pembagi informasi kepada penerima informasi. Sebagai sesuatu yang baru, seringkali difusi inovasi membawa suatu ketidakpastian bagi komunitas penerimanya. Komunitas penerima inovasi tersebut kemudian akan melakukan adopsi atau bersikap resisten terhadap ide-ide baru tersebut (Rogers, 1983).

Salah satu aspek dalam teori difusi inovasi adalah proses pengambilan keputusan inovasi. Paradigma proses pengambilan keputusan yang dikemukakan oleh Rogers (1981) merupakan teori yang paling banyak digunakan dan dinilai paling tepat (Nordin et. al., 2014), serta menjadi koreksi dari konsep proses pengambilan keputusan klasik (Mugniesyah, 2006). Rogers (1983) mengemukakan bahwa proses pengambilan keputusan inovasi merupakan sebuah proses mental di mana seorang individu melalui serangkaian tahapan-tahapan yang dimulai dari mengetahui suatu inovasi sampai pada 
pengambilan keputusan untuk menerima atau menolak dan dilanjutkan dengan mengukuhkan keputusan yang telah diambilnya. Tahapan umum yang dilalui dalam proses pengambilan keputusan ada lima, yaitu: tahap pengenalan, tahap persuasi, tahap pengambilan keputusan, tahap implementasi, dan tahap konfirmasi.

Difusi teknologi BJA untuk meningkatkan perluasan areal tanam kedelai di lahan pasang surut perlu dilakukan untuk meningkatkan produksi nasional kedelai yang secara jangka panjang dapat mengurangi ketergantungan Indonesia terhadap kedelai impor. Sebagai salah satu bentuk inovasi dalam bidang pertanian yang akan didifusikan secara luas pada petani, maka penelitian yang mengkaji proses pengambilan keputusan teknologi BJA pada tanaman kedelai oleh petani adopter potensial melalui pendekatan difusi inovasi penting untuk dilakukan. Penelitian ini bertujuan untuk menganalisis proses pengambilan keputusan adopsi inovasi BJA kedelai oleh petani adopter potensial di lahan pasang surut di Desa Labuhan Ratu Enam, Kabupaten Lampung Timur.

\section{METODE PENELITIAN}

\section{TAHAPAN PROSES KEPUTUSAN ADOPSI INOVASI}

Penelitian dilakukan di Desa Labuhan Ratu Enam, Kabupaten Lampung Timur, sejak bulan Oktober 2014 hingga Oktober 2015. Data yang digunakan adalah data primer dan sekunder. Pengumpulan data dilakukan melalui teknik: studi pustaka, wawancara dengan panduan kuisioner yang terstruktur, dan observasi. Responden penelitian ditentukan melalui sensus yaitu sejumlah 25 petani adopter potensial (calon adopter) yang merupakan petani sasaran difusi teknologi budidaya jenuh air pada tanaman kedelai di lahan pasang surut. Penelitian ini menggunakan analisis kualitatif-deskriptif dan analisis statistika nonparametrik. Analisis statistik deskriptif digunakan untuk memberikan gambaran proses pengambilan keputusan inovasi teknik budidaya jenuh air tanaman kedelai oleh petani. Setiap tahap dan derajat persepsi adopter potensial akan dievaluasi melalui pertanyaan tertutup dan derajat kesukaan dengan menggunakan skala Likert. Data yang diperoleh akan disajikan secara deskriptif. Uji Kruskall-Wallis digunakan untuk menganalisis perbedaan kategori pada karakteristik pengambil keputusan (pendidikan formal, pendidikan nonformal, pengalaman berusahatani, dan motivasi) terhadap tahap pengenalan. Uji Korelasi Peringkat
Spearman digunakan untuk menguji hubungan antar tahapan dalam proses pengambilan keputusan inovasi budidaya kedelai jenuh air, dan menguji hubungan karakteristik inovasi (kesesuaian, kerumitan, kemungkinan dicoba, dan kemungkinan diamati) dengan tahap persuasi.

\section{HASIL DAN PEMBAHASAN}

Sebagai salah satu area pilot project program difusi inovasi budidaya kedelai jenuh air, berbagai kegiatan telah dilakukan untuk menyebarkan informasi dan memberikan pengenalan kepada petani di Desa Labuhan Ratu Enam tentang inovasi budidaya kedelai jenuh air. Saluran komunikasi yang digunakan adalah komunikasi antarpribadi. Pada tahap awal pengenalan, inventor langsung turun ke lapang untuk memberikan pengetahuan mengenai inovasi budidaya kedelai jenuh air melalui diskusi klasikal, sekaligus praktik lapang di lahan petani. Pada tahap selanjutnya, tim peneliti mengutus satu orang pendamping lapang untuk menjadi agen pembaharu (change agent) yang bertugas untuk: i) mendiagnosis masalah dan merencanakan tindakan perubahan, ii) mengadakan hubungan dengan masyarakat untuk perubahan, iii) membangkitkan kebutuhan dan motivasi berubah pada diri adopter, iv) memelihara pembaharuan dan mencegah dari kemacetan.

Dari proses komunikasi yang dilakukan, sebagian besar responden (68\%) di Desa Labuhan Ratu Enam mendapatkan informasi dan pengenalan tentang budidaya kedelai jenuh air dari tim peneliti Institut Pertanian Bogor (IPB), sedangkan sebanyak 24\% mendapatkan informasi pengenalan budidaya kedelai jenuh air dari ketua kelompok tani atau anggota kelompok tani (sebagai opinion leader), dan 8\% lainnya melalui Petugas Penyuluh Lapang (PPL). Berdasarkan pengamatan peneliti, terdapat dua orang yang menjadi opinion leader yang memberi pengaruh terhadap perilaku anggota dalam kelompok taninya. Dalam proses difusi inovasi ini, 1 orang opinion leader mengajak 2 orang rekannya, sedangkan 1 orang opinion leader lainnya mengajak 3 orang rekannya, yang pada akhirnya menjadi petani adopter.

Agen pembaharu yang diutus kurang berperan dengan baik, sehingga menjadi salah satu kendala terbesar dalam proses difusi inovasi budidaya kedelai jenuh air di Desa Labuhan Ratu Enam. Hal tersebut disebabkan oleh agen pembaharu yang kurang bekerjasama dengan masyarakat, 
TABEL I. JUMLAH DAN PERSENTASE RESPONDEN YANG MENGENAL UNSUR DALAM PAKET TEKNOLOGI BUDIDAYA KEDELAI JENUH AIR DI DESA LABUHAN RATU ENAM

\begin{tabular}{|c|c|c|c|c|c|}
\hline \multirow{2}{*}{ No } & \multirow{2}{*}{ Unsur dalam Paket Teknologi Budidaya Jenuh Air (BJA) } & \multicolumn{2}{|c|}{ Responden yang Mengenal } & \multicolumn{2}{|c|}{ Responden yang Menyukai } \\
\hline & & Jumlah & Persentase (\%) & Jumlah & Persentase (\%) \\
\hline 1 & Kriteria lokasi di lahan Pasang surut tipe $B / C$. & 23 & 92,00 & 22 & 88,00 \\
\hline 2 & Waktu tanam yang tepat (April-Agustus). & 25 & 100,00 & 25 & 100,00 \\
\hline 3 & $\begin{array}{l}\text { Memilih benih unggul dan teruji (Tanggamus, Anjasmoro, } \\
\text { Cikuray). }\end{array}$ & 20 & 80,00 & 24 & 96,00 \\
\hline 4 & $\begin{array}{l}\text { Persiapan lahan (pembuatan saluran } \mathrm{I}=30 \mathrm{~cm} \mathrm{t}=25 \mathrm{~cm} \text {, } \\
\text { bedengan } \mathrm{I}=4 \mathrm{~m} \text { ). }\end{array}$ & 17 & 68,00 & 20 & 80,00 \\
\hline 5 & $\begin{array}{l}\text { Pemupukan (kapur } 1 \text { ton, SP-36 } 200 \text { kg, dan KCL } 100 \text { kg } \\
\text { dicampur dan disebar ke lahan seluas } 1 \text { ha) }\end{array}$ & 18 & 72,00 & 23 & 92,00 \\
\hline 6 & Penanaman (jarak tanam 40x12.5 cm, tiap lubang 2 biii). & 17 & 68,00 & 8 & 32,00 \\
\hline 7 & $\begin{array}{l}\text { Pengairan (air diberikan setinggi } 10 \mathrm{~cm} \text { dari dasar saluran } \\
\text { atau } 15 \mathrm{~cm} \text { dari permukaan tanah sejak tanam hingga } \\
\text { panen). }\end{array}$ & 19 & 76,00 & 15 & 60,00 \\
\hline \multirow[t]{2}{*}{8} & $\begin{array}{l}\text { Pemeliharaan (penyemprotan urea } 10 \text { gram/liter air, vol. } \\
\text { semprot } 400 \text { liter air urea/ha. Pada MST ke-3 s/d ke-6). }\end{array}$ & 21 & 84,00 & 23 & 92,00 \\
\hline & Pengendalian OPT (sesuai gejala). & 23 & 92,00 & 24 & 96,00 \\
\hline 10 & Panen (dipanen 10-15 hari lebih lama). & 11 & 44,00 & 21 & 84,00 \\
\hline
\end{tabular}

dan tidak menjalankan fungsinya dengan baik sehingga kredibilitas agen pembaharu kurang baik di mata masyarakat.

Dari pendekatan komunikasi yang dilakukan, berikut ini adalah lima tahapan dalam proses pengambilan keputusan yang dapat dipotret dari perilaku para petani calon adopter di Desa Labuhan Ratu Enam. Implikasi yang bisa ditarik dari hasil penelitian ini hanya berlaku (seluruhnya ataupun sebagian) pada pendekatan komunikasi yang telah dilakukan. Artinya, pendekatan komunikasi yang berbeda dapat menghasilkan dampak yang berbeda pula pada proses difusi teknologi baru dalam budidaya kedelai jenuh air.

Terdapat perbedaan dalam hal pengenalan responden terhadap sepuluh paket teknologi BJA, seperti terlihat dalam Tabel 1. Pengetahuan responden tentang beberapa unsur dalam paket teknologi masih kurang, antara lain tentang kriteria lokasi, penanaman, dan pengairan. Tahap persuasi merupakan tahap seseorang individu membentuk sikap suka atau tidak suka terhadap sebuah teknologi. Dalam mengevaluasi tahap persuasi dan melihat pembentukan sikap suka atau tidak suka, responden ditanyakan persetujuan responden terhadap setiap unsur paket teknologi. Pada Tabel 1, diketahui bahwa tidak semua petani yang mengenal teknologi BJA merasa nyaman terhadap unsur paket teknologi.

Tahapan keputusan sebagai tahap ketiga dari proses pengambilan keputusan adopsi teknologi BJA menunjuk pada aktivitas mental di mana petani memutuskan untuk menerima atau menolak anjuran paket teknologi budidaya kedelai jenuh air. Dalam tahap ini, petani yang mengadopsi teknologi yang dikenalkan dinamakan petani adopter, sedangkan petani yang menolak adopsi teknologi disebut petani nonadopter. Sebanyak 10 orang petani memutuskan untuk mengadopsi, sedangkan sisanya sebanyak 15 orang memutuskan untuk menolak adopsi teknologi budidaya kedelai jenuh air dan mempraktikkan usahatani dengan cara-cara lama yang dilakukan sebelumnya (Tabel 2). Petani yang memutuskan menolak adopsi beralasan merasa lebih merasa lebih nyaman dengan usahatani padi yang biasa mereka lakukan sebelumnya. Namun, sebagian petani yang memutuskan untuk mengadopsi teknologi budidaya kedelai jenuh air beralasan bahwa mereka tertantang untuk mencoba teknologi baru ini, sedangkan sebagian lainnya merasa membutuhkan inovasi bagi peningkatan produktivitas usahataninya.

Tahap implementasi adalah individu melaksanakan keputusan inovasi yang diambilnya dalam kehidupan nyata. Jika seorang petani telah memutuskan untuk mengadopsi inovasi maka dia akan menggunakannya dalam usahataninya. Sebaliknya, jika menolak, individu akan meneruskan cara-cara sebelumnya. Penelitian ini membatasi lingkup kajian hanya pada tahap implementasi dan konfirmasi petani adopter teknologi budidaya kedelai jenuh air, sedangkan tahap 
implementasi dan konfirmasi pada kelompok petani nonadopter tidak diamati. Pada tahap implementasi petani adopter, analisis yang dilakukan adalah seberapa besar tingkatan implementasi petani adopter terhadap sepuluh unsur paket teknologi budidaya kedelai jenuh air. Petani akan dikelompokkan ke dalam dua kategori, yaitu kategori implementasi rendah dan implementasi tinggi berdasarkan banyaknya elemen dalam paket teknologi budidaya kedelai jenuh air yang diterapkan sesuai anjuran.

Difusi teknologi BJA dikategorikan tinggi ketika minimal 7 (tujuh) unsur telah diterapkan oleh petani, sedangkan difusi teknologi BJA dikategorikan rendah ketika petani menerapkan kurang dari 7 (tujuh) unsur dalam paket teknologi BJA. Berdasarkan kriteria pengkategorian yang telah dibuat, sebanyak 7 orang (70\%) petani adopter teknologi budidaya kedelai jenuh air masuk kategori implementasi tinggi, dan sisanya sebanyak 3 orang (30\%) masuk kategori implementasi rendah.

Jika dilihat dari implementasi terhadap setiap elemen dalam paket inovasi budidaya kedelai jenuh air, terdapat elemen inovasi yang diimplementasikan oleh seluruh petani adopter, dan ada pula elemen inovasi yang hanya dilakukan oleh sebagian petani adopter. Sebagaimana diperlihatkan pada Tabel 4, elemen yang dilakukan oleh sepuluh atau sebagian besar petani adopter antara lain adalah pemilihan kriteria lokasi lahan pasang surut, penggunaan benih unggul, pemupukan awal, pembuatan saluran jenuh air, dan pengendalian OPT. Sementara itu, beberapa elemen inovasi, yaitu pengaturan jarak tanam, waktu tanam, pemanenan, dan pengairan hanya dilakukan oleh sebagian petani adopter. Sebagian elemen teknologi tidak dijalankan oleh petani dengan alasan petani melakukan tindakan penyesuaian dari anjuran dalam paket teknologi, misalnya jarak tanam (karena dianggap terlalu rapat), dan waktu panen (karena menghindari risiko gagal panen akibat masuk musim penghujan). Namun sebagian elemen inovasi tidak dilakukan karena petani merasa rumit dan mengeluarkan biaya dalam aktivitas tersebut, tanpa disertai sikap sabar untuk mengetahui hasil yang didapat dengan melaksanakan elemen teknologi tesebut sesuai anjuran.

Konfirmasi adalah pengukuhan, di mana individu mencari penguatan atas keputusan inovasi yang telah dibuatnya. Pada tahap ini, kelompok petani adopter dimungkinkan menghadapi dua pilihan konfirmasi adopsi teknologi, yaitu melanjutkan adopsi dan berhenti mengadopsi. Sementara itu, kelompok petani nonadopter
TABEL 2. JUMLAH DAN PERSENTASE RESPONDEN YANG MENGADOPSI DAN MENOLAK PAKET TEKNOLOGI BUDIDAYA KEDELAI JENUH AIR DI DESA LABUHAN RATU ENAM

\begin{tabular}{lll}
\hline Keputusan & Jumlah Orang & Persentase (\%) \\
\hline $\begin{array}{l}\text { Mengadopsi teknologi } \\
\text { budidaya kedelai jenuh air }\end{array}$ & 10 & 40,00 \\
$\begin{array}{l}\text { Menolak teknologi budidaya } \\
\text { kedelai jenuh air }\end{array}$ & 15 & 60,00 \\
\hline
\end{tabular}

TABEL 3. JUMLAH DAN PERSENTASE RESPONDEN YANG MENGIMPLEMENTASIKAN PAKET TEKNOLOGI BUDIDAYA KEDELAI JENUH AIR MENURUT JUMLAH PAKET DI DESA LABUHAN RATU ENAM

\begin{tabular}{lll}
\hline Jumlah Unsur Teknologi BJA & Jumlah & Persentase (\%) \\
\hline $\begin{array}{l}\text { Petani adtaterkedelai BJA kategori } \\
\text { implementasi tinggi }\end{array}$ & 7 & 70,00 \\
$\begin{array}{l}\text { Petani adtderkedelai BJA kategori } \\
\text { implementasi rendah }\end{array}$ & 3 & 30,00 \\
\hline
\end{tabular}

TABEL 5. JUMLAH PETANI YANG MELANJUTKAN ADOPSI DAN MENOLAK ADOPSI INOVASI BUDIDAYA KEDELAI JENUH AIR DI DESA LABUHAN RATU ENAM

\begin{tabular}{lll}
\hline Jumlah Unsur Teknologi BJA & $\begin{array}{l}\text { Jumlah } \\
\text { Orang }\end{array}$ & Persentase (\%) \\
\hline Petani adqderyang melanjutkan adopsi & 6 & 60,00 \\
Petani addpteryang berhenti mengadopsi & 4 & 40,00 \\
\hline
\end{tabular}

akan dihadapkan pada kemungkinan mengadopsi kemudian dan menolak adopsi. Kelompok petani adopter kategori implementasi tinggi kemungkinan besar melanjutkan adopsi, sedangkan petani adopter kategori implementasi rendah kemungkinan besar berhenti mengadopsi. Sebanyak 6 dari tujuh petani adopter kategori implementasi tinggi mengukuhkan keputusan adopsi teknologi budidaya kedelai jenuh air yang dilakukan sebelumnya. Petani tersebut akan mempraktikkan kembali teknologi budidaya kedelai jenuh air di musim tanam selanjutnya. Adapun ketiga petani implementasi rendah dan satu orang petani kategori implementasi tinggi pada tahap konfirmasi ini mengaku berhenti mengadopsi teknologi budidaya kedelai jenuh air. Petani yang melanjutkan adopsi menilai bahwa inovasi budidaya kedelai jenuh air meningkatkan produktivitas usahatani dan memberikan keuntungan relatif bagi mereka. Petani yang berhenti mengadopsi menilai bahwa teknologi ini 
TABEL 4. JUMLAH DAN PERSENTASE PETANI ADOPTER YANG MENGIMPLEMENTASIKAN UNSUR DALAM PAKET INOVASI BUDIDAYA KEDELAI JENUH AIR

\begin{tabular}{|c|c|c|c|}
\hline No & Unsur dalam Paket Teknologi Budidaya Jenuh Air (BJA) & $\begin{array}{l}\text { Jumlah Responden yang } \\
\text { meng-implementasi }\end{array}$ & $\begin{array}{l}\text { Persentase } \\
(\%)\end{array}$ \\
\hline 1 & Kriteria lokasi di lahan Pasang surut tipe $\mathrm{B} / \mathrm{C}$. & 10 & 100,00 \\
\hline 2 & Waktu tanam yang tepat (April-Agustus). & 2 & 20,00 \\
\hline 3 & Memilih benih unggul dan teruji (Tanggamus, Anjasmoro, Cikuray). & 10 & 100,00 \\
\hline 4 & $\begin{array}{l}\text { Persiapan lahan (pembuatan saluran } \mathrm{I}=30 \mathrm{~cm} \mathrm{t}=25 \mathrm{~cm} \text {, bedengan } \\
\mathrm{I}=4 \mathrm{~m} \text { ). }\end{array}$ & 9 & 90,00 \\
\hline 5 & $\begin{array}{l}\text { Pemupukan (kapur } 1 \text { ton, SP-36 } 200 \text { kg, dan KCL } 100 \text { kg dicampur dan } \\
\text { disebar ke lahan seluas } 1 \text { ha) }\end{array}$ & 10 & 100,00 \\
\hline 6 & Penanaman (jarak tanam 40x12.5 cm, tiap lubang 2 biii). & 3 & 30,00 \\
\hline 7 & $\begin{array}{l}\text { Pengairan (air diberikan setinggi } 10 \mathrm{~cm} \text { dari dasar saluran atau } 15 \mathrm{~cm} \\
\text { dari permukaan tanah sejak tanam hingga panen). }\end{array}$ & 5 & 50,00 \\
\hline 8 & $\begin{array}{l}\text { Pemeliharaan (penyemprotan urea } 10 \text { gram/liter air, vol. semprot } 400 \\
\text { liter air urea/ha. Pada MST ke-3 s-d ke-6). }\end{array}$ & 6 & 60,00 \\
\hline 9 & Pengendalian OPT (dg herbisida dan atau pestisida sesuai gejala). & 100 & 100,00 \\
\hline 10 & Panen (dipanen 10-15 hari lebih lama). & 4 & 40,00 \\
\hline
\end{tabular}

sedikit rumit dibandingkan dengan usahatani padi yang dilakukan sebelumnya dan lebih nyaman dengan usahatani padi.

\section{UJI BEDA VARIABEL DALAM KARAKTERISTIK RESPONDEN TERHADAP TAHAP PENGENALAN ADOPSI INOVASI KEDELAI BJA}

Uji Kruskal-Wallis dalam penelitian ini digunakan untuk menguji hipotesis adanya perbedaan dalam tahap pengenalan karena adanya perbedaan kategori faktorfaktor dalam karakteristik responden terhadap tingkat pengenalan dalam proses pengambilan keputusan. Diduga terdapat perbedaan pada tahap pengenalan dalam proses pengambilan keputusan adopsi inovasi kedelai BJA karena perbedaan kategori dalam variabel tingkat pendidikan formal, tingkat pendidikan nonformal, motivasi, dan pengalaman berusahatani.

Variabel pendidikan formal, pendidikan nonformal, motivasi, dan pengalaman berusahatani dikelompokkan kedalam beberapa kelompok. Tingkat pendidikan formal adalah jenis pendidikan sekolah tertinggi yang pernah diikuti oleh responden, dibedakan ke dalam kategori lamanya durasi pendidikan formal yang ditempuh, yaitu kurang dari 6 tahun, antara 7-9 tahun, antara 10-12 tahun, dan lebih dari 12 tahun. Tingkat pendidikan nonformal adalah total skor kegiatan pendidikan di luar sekolah (PLS) yang pernah diikuti oleh petani, baik pelatihan dan/atau kursus, seminar, lokakarya, pameran, mimbar sarasehan dan lainnya dilihat menurut tingkatan penyelenggaraannya (tingkat kampung, desa, kecamatan, kabupaten, provinsi dan nasional berturut-turut diberi skor 1 , skor 2, skor 3, skor 4 dan skor 5). Tingkat pendidikan nonformal dikelompokkan menjadi: i) skor PLS antara 1-5, ii) skor PLS antara 5-10, dan iii) skor PLS lebih dari 10. Tingkat motivasi atau kebutuhan petani terhadap inovasi BJA adalah kombinasi motivasi atau alasan petani untuk mengadopsi Inovasi BJA, yang dibedakan ke dalam kategori yang diadaptasi dari teori motivasi Maslow, yaitu: motivasi untuk meningkatkan produksi padi dan keuntungan, motivasi meningkatkan produksi dan keuntungan dan untuk menghindari risikorisiko produksi dari praktik budidaya kedelai terdahulu, serta bermotivasi meningkatkan produksi dan motivasi berkelompok atau untuk akumulasi modal. Tingkat pengalaman berusahatani adalah lamanya (tahun) petani responden menjalankan usahatani, yang dikelompokkan menjadi: pengalaman usahatani $<15$ tahun, pengalaman usahatani antara 16-30 tahun, pengalaman ushatani lebih dari 30 tahun.

Berdasarkan hasil uji Kruskal-Wallis, dapat disimpulkan bahwa terdapat perbedaan yang signifikan nilai tahap pengenalan responden berdasarkan tingkat pendidikan nonformal dan motivasi. Hal tersebut dapat dilihat dari nilai signifikasi uji yang lebih kecil dari nilai á yang digunakan $(0,011$ dan 0,004$)$. Sementara itu, dari aspek pendidikan formal dan pengalaman usahatani 
tidak menunjukkan adanya perbedaan yang signifikan dalam tahap pengenalan, karena nilai signifikasi yang lebih besar daripada nilai á yang digunakan. Secara terperinci output hasil uji Kruskal-Wallis ditampilkan dalam Tabel 6.

Umumnya, tingkat pendidikan diasumsikan memiliki keterkaitan dengan pola pikir dan kemampuan seseorang dalam menyerap dan mengolah sebuah informasi.

Semakin tinggi tingkat pendidikan formal maka semakin cepat pula menangkap dan mengolah informasi berupa inovasi teknologi baru, sehingga diduga perbedaan tingkat latar belakang pendidikan formal akan menyebabkan perbedaan dalam tahap pengenalan inovasi budidaya kedelai jenuh air. Namun berdasarkan uji Kruskal-Wallis yang dilakukan menunjukkan hal yang berbeda. Perbedaan tingkat pendidikan formal tidak menyebabkan perbedaan dalam tahap pengenalan.

Begitu pula dalam variabel pengalaman usahatani. Pengalaman usahatani diasumsikan memengaruhi keterampilan seorang petani. Petani yang memiliki pengalaman bertani yang cukup lama dianggap akan lebih baik dan cepat dalam mengenal teknologi baru dengan mempertimbangan keberhasilan dan kegagalan di masa lalu dibandingkan petani yang memiliki pengalaman yang lebih sedikit. Namun, sama halnya dengan variabel pendidikan formal, berdasarkan uji Kruskal-Wallis yang dilakukan menunjukkan bahwa perbedaan tingkat pengalaman berusahtani tidak menyebabkan perbedaan dalam tahap pengenalan.

\section{UJ KORELASI PERINGKAT SPEARMAN UNTUK MENGANALISIS HUBUNGAN EMPAT KARAKTERISTIK INOVASI KEDELAI BJA TERHADAP TAHAP PERSUASI}

Terdapat lima ciri atau karakteristik inovasi yang mendasari penerimaan atau persepsi individu terhadap inovasi menurut Rogers (1983), yaitu: keuntungan relatif, kerumitan, kesesuaian, kemungkinan dicoba, dan kemungkinan diamati. Di antara lima karakteristik inovasi tersebut, empat diantaranya ingin dilihat bagaimana hubungannya dengan tahap persuasi teknologi kedelai BJA melalui analisis Korelasi Peringkat Spearman. Keempat karakteristik inovasi yang digunakan adalah kerumitan, kesesuaian, kemungkinan dicoba, dan kemungkinan diamati. Aspek keuntungan relatif kedelai BJA tidak dilibatkan dalam analisis hubungan terhadap tahap persuasi karena dalam bagian analisis usahatani dalam penelitian ini akan tergambar bagaimana keuntungan relatif dari inovasi BJA ini secara ekonomi.

Diduga tiga karakteristik inovasi (kesesuaian, kemungkinan dicoba, dan kemungkinan diamati)

TABEL 6. MEAN RANK DAN HASIL UJI BEDA VARIABEL DALAM KARAKTERISTIK RESPONDEN TERHADAP TAHAP PENGENALAN ADOPSI INOVASI BUDIDAYA KEDELAI JENUH AIR

\begin{tabular}{llllll}
\hline Variabel & Kelompok & N & Mean Rank & Chi-Square & Asymp. Sig. (2-tailed) \\
\hline Pendidikan & $\leq 6$ tahun & 8 & 8,81 & 5,997 & 0,112 \\
formal & $6<x \leq 9$ tahun & 5 & 11,30 & & \\
& $9<x \leq 12$ tahun & 9 & 15,94 & & \\
& $12<x$ tahun & 3 & 18,17 & & \\
& Total N & 25 & & & 0,011 \\
\hline Pendidikan & $\leq 5$ & 8 & 7,94 & 9,064 & \\
nonformal & $5<x \leq 10$ & 12 & 13,33 & & \\
& $10<x$ & 5 & 20,30 & & 0,005 \\
& Total N & 25 & & & \\
\hline Motivasi & $1^{*}$ & 17 & 9,85 & 10,590 & \\
& $2^{* *}$ & 4 & 17,88 & & 0,731 \\
& $3^{* * *}$ & 4 & 21,50 & & \\
\hline Pengalaman & Total N & 25 & & & \\
usahatani & $16<x<30$ tahun & 8 & 14,25 & & \\
& $30<x$ tahun & 12 & 12,83 & & \\
& Total N & 25 & & & \\
\hline
\end{tabular}

Keterangan:

*) Meningkatkan produksi dan keuntungan

**) Meningkatkan keuntungan dan menghindari risiko

***) Meningkatkan keuntungan, motivasi berkelompok, dan akumulasi modal 
mempunyai hubungan positif dengan tingkat persuasi, sedangkan kerumitan mempunyai hubungan negatif dengan tingkat persuasi.

Berdasarkan hasil output uji Korelasi Peringkat Spearman pada Tabel 7, dapat dilihat bahwa terdapat korelasi yang signifikan antara variabel kerumitan dan kemungkinan dicoba dengan tingkat persuasi dalam proses keputusan inovasi teknologi kedelai BJA. Kerumitan berkorelasi negatif terhadap tingkat persuasi dengan koefisien sebesar -0,423, sedangkan kemungkinan dicoba berkorelasi positif dengan koefisien 0,448.

Keduanya signifikan pada taraf nyata 5\%. Di sisi lain, dua variabel karakterik lainnya, yaitu kesesuaian dan kemungkinan diamati, tidak menunjukkan hubungan yang signifikan dengan tingkat persuasi.

\section{TABEL 7. HASIL UJI KORELASI SPEARMAN KARAKTERISTIK INOVASI DENGAN TAHAP PERSUASI DALAM PENGAMBILAN KEPUTUSAN ADOPSI INOVASI BUDIDAYA KEDELAI JENUH AIR}

\begin{tabular}{llll}
\hline & & \multicolumn{2}{l}{ Uji Korelasi Peringkat } \\
& \multirow{2}{*}{ Variabel/Aspek Uji } & $\begin{array}{l}\text { Koefisien } \\
\text { Korelasi }\end{array}$ & Nilai \\
& & 0,350 & Sigifikasi \\
\hline A & Kesesuaian-Tahap Persuasi & 0,087 \\
B & Kerumitan- Tahap Persuasi & $-0,423^{*}$ & 0,035 \\
C & Kemungkinan dicoba- Tahap Persuasi & $0,448^{*}$ & 0,025 \\
D & Kemungkinan diamati-Tahap Persuasi & 0,247 & 0,233 \\
\hline
\end{tabular}

Penerimaan (psikologis) para petani terhadap inovasi teknologi kedelai BJA yang lebih berhubungan dengan aspek kerumitan dapat dipahami sebagai akibat dari banyaknya unsur yang perlu diimplementasikan. Sifatnya yang merupakan kesatuan paket teknologi dapat dirasakan lebih rumit dibandingkan dengan teknologi yang lebih sederhana. Hal ini terutama dapat terlihat (pada Tabel 4 subbab sebelumnya) dari rendahnya persentase jumlah responden yang menyatakan suka terhadap unsur cara penanaman $(32 \%)$ dan pengairan (60\%) dalam teknologi BJA. Bagi sebagian besar petani yang biasanya cukup menebar benih untuk menanam padi (sebagai praktek usahatani sebelumnya), misalnya, teknik penanaman dengan jarak tanam tertentu dan dengan metode setiap lubangnya diberi 2 biji tentu saja cukup memberatkan. Begitu pula dengan menjaga tingkat pengairan pada tinggi tertentu dari awal penanaman hingga panen.

Selain aspek kerumitan, tingkat persuasi dalam proses adopsi teknologi kedelai BJA ini juga berkorelasi positif dan signifikan dengan aspek kemungkinan dicoba. Aspek kemungkinan dicoba adalah kondisi ketika sebuah inovasi dapat dicobakan dalam skala kecil. Hal ini karena dimungkinkan karena inovasi yang dapat dicoba dalam skala kecil akan menurunkan risiko bagi penerimannya jika inovasi tersebut dicobakan dalam skala yang lebih luas. Hal tersebut karena prinsip kerja BJA yang menitikberatkan pada pengelolaan air yang dapat mengoptimalkan daya kerja tanah, suhu, benih, dan radiasi sinar matahari untuk mengoptimalkan hasil usahatani yang didapatkan (melalui peningkatan produktivitas), sangat mudah diterapkan pada lahan petani. Secara umum, penggunaan input dalam usahatani kedelai BJA sama dengan input lain yang digunakan oleh petani dalam usahatani yang biasa dilakukan, seperti tanah, tenaga kerja, pupuk, benih, air, dan sebagainya. Tidak ada input khusus dalam BJA ini (yang belum pernah petani gunakan oleh petani pada usahatani sebelumnya).

\section{UJI KORELASI PERINGKAT SPEARMAN DALAM ANALISIS HUBUNGAN ANTARTAHAPAN PROSES PENGAMBILAN KEPUTUSAN INOVASI}

Proses pengambilan keputusan inovasi, secara teoritis, terdiri dari lima tahapan yang saling berhubungan.

Dalam proses adopsi inovasi budidaya kedelai jenuh air, hubungan antartahapannya dianalisis dengan uji korelasi peringkat Spearman. Berdasarkan hasil output uji Korelasi Peringkat Spearman, tahap pengenalan inovasi kedelai BJA berkorelasi positif dengan tahapan persuasi inovasi kedelai BJA. Demikian pula terdapat hubungan positif antara tahap persuasi dengan tahap pengambilan keputusan, dan antara tahap implementasi dengan tahap konfirmasi. Ketiganya signifikan pada taraf nyata 5\%. Hasil uji korelasi antar tahapan tersebut ditampilkan pada Tabel 8 .

Hasil di atas menunjukkan kecenderungan bahwa semakin baik tingkat pengenalan petani terhadap teknologi inovasi budidaya kedelai jenuh air, semakin tinggi tingkat persuasi yang dirasakan, dan semakin tinggi pula kemungkinan keputusan adopsi paket teknologi tersebut. Demikian pula sebaliknya. Selain itu, semakin baik tingkat implementasi teknologi BJA, semakin tinggi pula kecenderungan pengadopsian kembali teknologi ini. Artinya, hasil yang diperoleh dari penerapan teknologi BJA sesuai dengan yang dibayangkan oleh mayoritas petani adopter sehingga berkenan untuk melanjutkannya di masa mendatang. 
TABEL 8. HASIL UJI KORELASI SPEARMAN ANTARTAHAPAN INOVASI BUDIDAYA KEDELAI JENUH AIR

\begin{tabular}{llll}
\hline & & \multicolumn{2}{l}{ Uji Korelasi Peringkat Spearman } \\
\cline { 3 - 4 } & Variabel/Aspek Uji & $\begin{array}{l}\text { Koefisien } \\
\text { Korelasi }\end{array}$ & Nilai Sigifikasi \\
\hline A & $\begin{array}{l}\text { Tahap Pengenalan-Tahap } \\
\text { Persuasi }\end{array}$ & $0,457^{*}$ & 0,022 \\
B $\quad \begin{array}{l}\text { Tahap Persuasi-Tahap } \\
\text { Pengambilan Keputusan }\end{array}$ & $0,486^{*}$ & 0,014 \\
C $\quad \begin{array}{l}\text { Tahap Implementasi-Tahap } \\
\text { Konfirmasi }\end{array}$ & $0,083^{* *}$ & 0,001 \\
\hline
\end{tabular}

Catatan: ${ }^{* *}$ ) Signifikan pada taraf nyata $1 \%$, *) Signifikan pada taraf nyata 5\%

\section{DISKUSI}

Proses difusi inovasi dimungkinkan berlangsung karena ada unsur-unsur pendukungnya. Terdapat empat unsur utama dalam difusi inovasi, sebagaimana diungkapkan oleh Rogers (1983), yaitu: inovasi, saluran komunikasi, waktu, dan sistem sosial. Pendekatan proses pengambilan keputusan adopsi inovasi yang telah dilakukan dan menjadi concern dalam penelitian ini, mengindikasikan bahwa dari aspek inovasi itu sendiri (yang dicirikan dengan empat karakteristik inovasi budidaya kedelai BJA; kesesuaian, kerumitan, kemungkinan diamati, dan kemungkinan dicoba) menjadi elemen yang dominan dalam proses difusi inovasi budidaya kedelai jenuh air di Desa Labuhan Ratu Enam, Lampung Timur.

Dilihat dari elemen proses difusi yang lain, yaitu pendekatan komunikasi, dapat dilihat bahwa saluran komunikasi yang digunakan dalam proses difusi teknologi budidaya kedelai jenuh air dapat dikatakan berjalan tidak cukup efektif. Hal ini terlihat dari persentase petani yang akhirnya mengadopsi teknologi BJA hanya 40\% (10 dari 25 orang). Dalam proses komunikasi yang dilakukan, saluran komunikasi yang digunakan adalah komunikasi antarpribadi oleh tim peneliti LPPM IPB dan agen pembaharu. Namun dalam praktiknya, agen pembaharu yang diutus kurang bekerjasama dengan masyarakat, dan tidak menjalankan fungsinya dengan baik, sehingga mengakibatkan kredibilitas agen pembaharu kurang baik dimata masyarakat. Sebagai implikasinya, agen pembaharu kurang berperan dalam proses difusi inovasi budidaya kedelai jenuh air di Desa Labuhan Ratu Enam.

Jaringan sosial dalam sistem sosial merupakan sarana yang memungkinkan terjadinya penyebarluasan informasi tentang inovasi. Dalam sistem sosial di Desa Labuhan Ratu Enam, terdapat peran beberapa opinion leader dalam proses difusi inovasi teknologi budidaya kedelai jenuh air hingga akhirnya mempengaruhi perilaku beberapa petani untuk mengadopsi BJA.

Namun demikian, sebagian besar petani adopter merasakan impresi yang baik dari usahatani baru mereka ini (budidaya kedelai jenuh air). Hal itu terlihat dari tingkat konfirmasi mereka terhadap usahatani kedelai yang cenderung menjadi lebih tinggi pascaadopsi inovasi budidaya kedelai jenuh air. Salah satu faktor utama yang membentuk impresi baik tersebut adalah tingkat pendapatan atau keuntungan yang mereka peroleh, dimana pendapatan tersebut selaras dengan tingkat implementasi teknologi yang telah mereka lakukan. Dengan kata lain, teknologi budidaya kedelai jenuh air ini sebenarnya dapat memenuhi ekspektasi (baik dari segi teknis maupun ekonomis) dari para petani adopter yang telah menerapkannya dengan baik. Kendala yang dihadapi dalam proses difusi teknologi baru ini lebih kepada pendekatan saluran komunikasi yang dijalankan, sehingga keberhasilan dalam mengajak petani potensial untuk mengadopsi teknologi budidaya kedelai jenuh air ini belum optimal.

\section{KESIMPULAN}

Berdasarkan pendekatan komunikasi yang dilakukan, dapat disimpulkan bahwa saluran komunikasi yang digunakan dalam proses difusi berjalan tidak cukup efektif, yang dibuktikan dari rendahnya tingkat adopsi, hanya $40 \%$ petani yang akhirnya mengadopsi teknologi BJA. Tingkat pengenalan petani terhadap BJA dipengaruhi tingkat pendidikan non formal dan motivasi, sedangkan tingkat pendidikan formal dan pengalaman berusaha tani tidak berpengaruh nyata.

Tingkat persuasi yang dirasakan oleh petani tentang BJA ternyata berhubungan secara signifikan dengan aspek kerumitan dan kemungkinan dicoba, namun tidak dengan kesesuaian dan kemungkinan diamati. Terdapat hubungan positif yang signifikan antara tahap pengenalan dengan tahap persuasi, tahap persuasi dengan tahap pengambilan keputusan, dan tahap implementasi dengan tahap konfirmasi. Sebagian besar petani adopter merasakan impresi yang baik dari usahatani baru mereka ini (budidaya kedelai dengan teknologi BJA). Hal itu terlihat dari tingkat konfirmasi mereka terhadap usahatani kedelai BJA yang menjadi lebih tinggi 
pascaadopsi inovasi budidaya kedelai jenuh air.

Implikasinya, untuk mengefektifkan proses difusi teknologi budidaya kedelai jenuh air hendaknya, i) para petani yang menjadi target calon adopter di masa mendatang adalah mereka yang memiliki motivasi, keterampilan, dan pengalaman usahatani yang tinggi; ii) agen pembaharu yang menjadi salah satu instrumen kunci dalam proses adopsi inovasi agar dapat menjalankan fungsinya dengan baik; iii) proses difusi menggandeng opinion leader di masyarakat agar proses difusi inovasi dapat dilakukan lebih efektif sehingga tujuan difusi inovasi tercapai optimal.

\section{DAFTAR PUSTAKA}

Adisarwanto, T. A., \& Wudianto, R. 2002. Meningkatkan Hasil Panen Kedelai di Lahan Sawah-Kering-Pasang Surut. Penebar Swadaya, Jakarta.

Ghulamahdi, M. 2014. Standard Operational Procedure Budidaya Jenuh Air Tanaman Kedelai.

Ghulamahdi, M., Melati, M., \& Sagala, D. 2009. Production of soybean varieties under saturated soil culture on tidal swamps. J. Agron. Indonesia 37(3): 226-232.

Hunter, M. M., De Fabrun, P. L. M., \& Byth, D. E. 1980. Response of nine soybean lines to soil moisture conditions close to saturation. Australia Journal Exp. Agricultural Animals. Husb. 20: 339-345. Irianto, G. P., Rejekiningrum, Sumarni, E., \& Estiningtyas, W. 2005
Pewilayahan dan pengembangan kedelai di lahan suboptimal. Dalam Pengembangan Kedelai di Lahan Suboptimal. Makarim, A. K., Suharsono, Arsyad, D. M., Adisarwanto, T., Marwoto, Saleh, N., Winarto, A., \& Kuncoro, B.S., (Ed). Malang, 26-27 Jul.

Makarim, A. K., Arsyad, D. M., \& Ghozi, A. 2005. Model simulasi peningkatan produksi kedelai di lahan suboptimal. Dalam Pengembangan Kedelai di Lahan Suboptimal. Makarim, A. K., Suharsono, Arsyad, D. M., Adisarwanto, T., Marwoto, Saleh, N., Winarto, A., \& Kuncoro, B.S., (Ed). Malang, 26-27 Jul.

Mugniesyah, S. S. 2006. Penyuluhan Pertanian. IPB, Bogor.

Mugniesyah, S. S., \& Lubis, D. P. 1990. Studi Hubungan Tipe Pengambilan Keputusan Inovasi Supra Insus dengan Adopsi Supra Insus di Tingkat Petani dan Kelompok Tani (Studi Kasus di WKPP Tambakdahan dan WKPP Mariuk, WKBPP Binong Subang, Jawa Barat). Pusat Studi Pembangunan, LPPM IPB.

Nordin, S. M., Noor, S. M., \& Saad, M. S. 2014. Innovation diffusion od new technologies in the malaysian paddy fertilizer industry. Procedia-Social and Behavioral Science 109: 768-778.

Rogers, E. M. 1983. Diffusion of Innovation: A Ctoss-Cultural Aproach. The Free Press. Collier MacMillan Publisher, London.

Sudana, W. 2005. Potensi dan prospek lahan rawa sebagai sumber produksi pertanian. Jurnal Analisis Kebijakan Pertanian 3(2): 141 151.

Supadi. 2009. Dampak impor kedelai berkelanjutan terhadap ketahanan pangan. Jurnal Analisis Kebijakan Pertanian 7(1): 87-102. 